\title{
Symbolic Meanings of Keo Traditional House in Flores, Indonesia
}

\author{
Klemens Mere ${ }^{1}$ \\ Bonaventura Ngarawula² \\ ${ }^{1}$ Faculty of Economics, University of Wisnuwardhana, Malang, East Java, Indonesia \\ ${ }^{2}$ Faculty of Social and Political Sciences, University of Merdeka, Malang, East Java, Indonesia
}

\section{Doi:10.5901/mjss.2015.v6n4s3p500}

\begin{abstract}
In the past, traditional house of Keo community (Sao Pu'u) had functions not only as a shelter, but it was symbols of social unity and as the center of various activities undertaken by community members. In a village, it can be found more than one unit of traditional house. The symbols are visible on the traditional houses reflect their togetherness, cooperativeness and the spirit of belonging. Keo's traditional house has very complex symbolic meanings of leadership, magic, power, prosperity, struggle, and purity.
\end{abstract}

Keywords: traditional house, Keo, magic, community, Flores

\section{Introduction}

In the face of social change, there exists dynamics and phenomena in the behavior of community members and it can be seen when they adapt to its environment. The same circumstances are experienced by the Keo community in the village Lajawajo, sub-district Mauponggo, district Ngada, Flores, in the province of East Nusa Tenggara. We will give attention to cultural values, functions, and symbolic meanings of Keo community's traditional house. The study on the traditional house will be seen in the context of changes in society, with emphasis on response and adaptation to the changes.

We observe the relationship between cultural values of traditional houses, function and symbolic meanings to the reality of social change that will determine the preferences and survival of local communities. It is understandable therefore for Keo community that traditional house is a series of customs and as a center of community activities. All forms of activities in the traditional house are very influential on their daily lives. The local community is very uphold the cultural values of the traditional house as well as the activities associated with it. Series of traditional party activities usually are held when building the main house or traditional house (sao pu'u) which are built in the middle of the village and became a symbol of unity, harmony and togetherness. The traditional parties are also held at the time of embedding the monument in the center of the traditional village, which is known as ngadhu bhaga or peo. From this activities and buildings, it reflects a range of cultural values, functions and symbolic meanings. With regard to the cultural values of traditional houses, function and symbolic meanings as well as the process of social change, slowly we can find that there has been a change in the structure of local communities included in the farm system. Based on that fact, the purpose of the article is to reveal the symbolic meanings of Keo traditional houses in the village Lajawajo, in the context social changes.

\section{Literature Reviews}

\subsection{Culture Definition}

Culture is the whole aspect of the way of life of a community. Culture can be obtained in the community through learning and sharing with fellow citizens and an accumulation of learning outcomes and experiences of humanity in a society (Keesing, 1981). Culture can also be termed as a whole social heritage of a society (Broom et al, 1963), which is a complete plan for their life and a whole way of life that is institutionalized in a society (Bertrand, 1967; Ballantine, 1993). Cultures encompass approved ideas and practices and are performed by many residents on how they respond to natural and social conditions they face and the organization of the phenomenon that relies on the use of symbols, whether with regard to actions, ideas, sentiments, and the object. The culture contains a set of rules and procedures that are used as a 
benchmark of how things should be done, along with a set of ideas and values that sustain them. Meanwhile, the culture includes cultural objects such as language, ideas, norms, tools, and well-organized institutional system that arrange patterns of social life of a community.

Meanwhile, according to Koentjaraningrat (1990), the culture is described as a whole system of ideas, actions and results of the work of human beings in order to serve a society that belongs to human beings through learning. He further explained that the culture can be divided into three states namely: (1) a form of culture as a complex of ideas, ideas, values, norms, rules, (2) a form of culture as a complex pattern of actions by human activities in the community, and (3) a form of culture as objects of human handiwork. Kluckhohn (1962) took the essence of the various frameworks of universal cultural elements found in all nations of the world. Seven elements that can be seen as the main content of every culture in the world are: language, knowledge system, social organization, system of life equipment and technology, (5) livelihood system, (6) religious system, and art. All the seventh element of the universal culture of each course also has a physical form, although no one physical form for the all of the elements of universal culture. That is why physical culture does not need to be specified according to the four cultural and social systems.

\subsection{Culture as a Way of Life}

Culture, as a way of life, can be formulated as reinforce mutual interaction between cultural bias (values and norms that are believed) and social practice (social relations) (Thompson, 1990). The way of life is a combination of social relations and values or norms that are believed. The growth of cultures as a way of life depends on mutually supportive relationship between cultural biases and social relationships. Culture as a way of life is associated with the views of the work. The pattern is often referred to as the work culture. Geertz (1973) stated that the culture work is as a spiritual wealth in the form of a fundamental attitude toward self and the world which were reflected in everyday life.

The culture of a society can change. Factors that cause the change of culture in society are not only come from outside the community or because it comes in contact with the outside world, but it can also occur as a result of a dynamic process that occurs in the community itself, such as increasing or decreasing the number of people, personal or group interests, competition, the emergence of new ideas (innovation). The level of needs, direct benefits obtained, competition, reward or punishment, as well as novelty (novelty) are all factors driving the changes that occur in society and human culture (Arensberg, et al., 1971). Therefore, culture can lead to the desired changes of society, and can also be ignored if it does not have merit. Related to the facts, Suparlan (1987) explained that every culture in the community usually has supporting and inhibiting factors for the acceptance of things or new ideas.

\subsection{Social and Cultural Conditions of Village Lajawajo}

People of village Lajawajo are part of Keo community or tribe Keo which is considered as a native. They inhabit subdistrict Mauponggo and known as ata Keo or ata ma'u. In general, residents of the village Lajawajo are called ata Keo. The language they use can be divided into two major categories, namely the population groups who inhabit villages around the Mauponggo coast with dialect and accent Ende which has different language with dialect Keo who inhabit the villages in the mountains. In general, when we see from the social and cultural conditions, villagers of Lajawajo have a unique interest to be explored more deeply, as the existence of suko bu'e class or youth groups who are are often abbreviated as SB. Each SB has its own name according to its preference.

Keo community has special cultural values and traditions which are social, harmonious, mythical, magical, superstition, symbolic, ethical, and religious. The distinctive properties of the Keo community are already existed on the ancestors who then handed down. In everyday life, Keo community always thinks lives and acts socio-collectively. Sociocollective thinking is a human activity which sees them live in unity with others in the group, in the tribe and in the community. Because of the importance of another people, the symptoms of social-collective thinking appear. One person will only have meaning only if he is involved in overall social life because in togetherness he can survive. The way how to live like that has been maintained in the Keo community. Thoughts and feelings of social-collective are based on Keo's kinship; marriage and tribal which make all citizens think social-collective and mutual solidarity.

\subsection{Traditional House of Keo Community}

In studying the cultural values in the context of social changes in Keo community, a major concern is addressed in things that seem very prominent such as the existence of the traditional house (sao pu'u). The traditional house of the Keo community in the past had function not only as a shelter, but also as a symbol of social unity and as the center of various 
activities undertaken community members. So that in general, the one unit of Keo community comes from people of previous generation of indigenous who inhabited the same house long time ago. In Keo community, we can find more than one unit of traditional house. In sub-district Mauponggo, the traditional house is known as sa'o waja or sa'o pu'u. Each group of tribal people calls it with a variety of terms according to their tribal language. Word waja or pu'u probably came from Keo pu'u which means source. Each traditional house is inhabited by six to ten units of family, and each family occupies a cubicle or a separate room. The height of a traditional house is between eight to fifteen feet (4.5 meters) from the ground with a length to reach approximately one hundred feet (30 meters). Most of the traditional houses are not maintained and many are destroyed after the independence of the Republic of Indonesia. The damage of the traditional house in the area of Keo community is as a result of the government's reccommendation for the society to build smaller house for a smaller group (for each family). There was a report that in the region of Central Flores in 1985 the local government has issued rules that each family unit must build a permanent house for shelter. In order to deal with this situation, the local government has launched a program of restoration for traditional houses in rural areas in attempt to preserve local culture as a form of national culture of Indonesia and to attract tourists.

\section{Methodological Framework}

In line with Back and Champion (1976), the social unity is in this study Keo community, while social unit that is targeted is Nua Bolo. As a study case, the research results cannot be generalized beyond the Keo community, instead it can be used as an analytical tool for reading social phenomena in other communities that have a similar character and characteristics. The type of case studies used for this research is a case study of situation analysis which is used to examine events that appear in society because of changes in cultural values. Judging from the process, this study is a field qualitative research by emphasizing methods of observation and interviews. Merriam (2009) asserted that qualitative research is a research procedure that produces descriptive data in the form of written or spoken words of citizens and actors that can be observed. Qualitative research approach is used because it is suitable to the problems studied.

\subsection{Analysis and Observational Unit}

The unit of analysis in this study is the development of the traditional house and the custom monument (Peo). The development of the traditional house includes: (a) determining the type of wood, (b) finding suitable location, (c) determination of indigenous design, (d) budget drafting, (e) shelter (f) purification process, ( $g$ ) determination of roofing, and $(h)$ the blessing or consecration. While the establishment of indigenous custom monument includes (a) determining the type of timber, (b) finding suitable location, (c) determination of customary design, (e) budget drafting, (f) road detention, (g) engraving process, (h) purification process, (i) setting-up main post, and (j) blessing.

Meanwhile, the observation unit in this study is the cultural values in the context of social chages in a Keo community. This research was conducted in the village Lajawajo of sub-district Mauponggo, district Ngadha, Flores, East Nusa Tenggara. Lajawajo village designated is as the research location with the following consideration and: (1) social transformation in the village shows harmony and very different from other areas that show the disintegration condition, (2) the location is easily accessible and in term of time, the data mining can be in flexible manner in order to obtain more detailed information on target research.

\subsection{Data Source}

Sources of information and data sources can be in forms of human and non-human which include documents and records/notes. These sources need to be chosen appropriately in order to provide accurate information about the observed phenomena. In accordance with this, the main human resources (informants) in the research to obtain primary data are: (1) tribal chiefs, (2) intellectual figures, (3) religious figures, and (4) officers of local government. Meanwhile, the non-human resources to obtain secondary data are the documents, records and files related to social interaction of Keo community in sub-district Mauponggo.

\subsection{Techniques of Data Analysis}

In this research, we perform data analysis as the one which has developed by Glasser and Strauss (1967) in a grounded theory study. The data collected is analyzed by induction, which is used to describe the dynamics and live development of Keo community and its struggle with social phenomena. Meanwhile, interpretative analysis is used to understand the 
meanings and symbols as well as the actions taken by the community in relation to changes in cultural values, especially among members of Keo community in the village Lajawajo. While relationship analysis is used to understand the rationalization of the relationship between the actions carried out among the community members in cultural change, whether in the form of real or artificial.

\section{Results and Discussion}

Traditional house is a building for living together with those who are originating from the same tribe, where a sacred ceremony is held by the tribe. For Keo community, the traditional house is an important building for tribal unity, and called sa'o pu'u if it is meant the building. But if it is intended as a tribal gathering, deliberation, or meeting place, then they call it as sa'o waja.

There are many rites of life in a traditional house Keo. The existence of all the rites that bring social-collective spirit play major role in the life of families and communities. An example is the occurrence of pregnant woman who live at a traditional house. They consider the pregnancy is not solely as a woman's reproductive process, but more than that. Pregnancy brings excitement to the tribe because they assume that the child in the womb is a new citizen and successor of the tribe who is living in the environment of traditional house and the Keo community. Honour and pride of the tribe has been felt at the time. The whole families rejoice and attentively follow the way of life and behavior of the woman who is pregnant and expecting for her safety.

Keo traditional house is generally located in a single circular chain, joined into a traditional village. In the middle of the traditional house, it is placed a kind of monument which made of wooden carvings, called Peo. The existence of the Peo symbolically shows that there is always a leader in the indigenous areas. The Peo is believed to drain the positive characteristics by shining the four powers as follows:

(a) Willpower, which is the power of the warrior archetype.

Most of the leaders began to make his career at the top of this archetype. The warriors learn to discipline themselves, intensely focused on their task and willing to sacrifice time and energy to fulfill the required by other leaders or the village. Someone with a determination would be willing to sacrifice for the bigger inter-personal purpose. These warriors show strong loyalty to the people and the principle of loyal and honest in fulfilling whatever is necessary to serve others, organization, or the world. When someone moves forward in positions of leadership, determination of archetypes warriors need arises more.

(b) Wisdom

Wisdom magically appears because it is a combination of skills and knowledge about something that passes through various experiences and moves out of the habit of becoming art. Master certain art means someone gained a certain level of control and has the ability to use the art to change the situation. Wisdom and determination are usually used by leaders to advance in the organization. People get promotions because of hard work and experience. Leadership is often identified through cleverness in solving problems. Hard work and master the knowledge and skills are a zone that is convenient for general leaders, and then many leaders rely on willpower and wisdom when facing difficulties.

(c) Mercy

This is the power of human archetypes. Understanding these strengths in traditional leadership requires the meaning of the word 'compassion'. Compassion is a combination of Latin, cum which means 'with' or 'together' and the passion comes from the word passia or pati, which means suffering (mercy). Then compassion literally means have the intention to suffer along with everyone else. Empathy and creativity are the methods used by the leaders to deal with adversity and challenging situations. The essence of leadership is that suffering has a tendency toward strong feelings and emotions, passion, intensity, earnest interest, devotion, and compassion in addition to a love for people and things. Compassion or care feelings always warm a leader. Willpower of warriors can make the leader to be cool and full of consideration. If it appears to reality, then it will promote leadership qualities such as spontaneity, humour, creative innovation, and wholeheartedly as well as fun activities. Compassion is the spiritual center of a leader. Compassion is the point of a compass that directs the power of the others. The leader will motivate its citizens with devotion, generate affection in the relationship of power with his followers and provide care to local residents.

(d) Presence

It is the archetype of power, or the characteristics of a king or queen in leadership. Strength and presence in a leader gives context of energetic force. Give a strong impetus to someone can develop emotional ties or personal relationships in a village or community. The presence of a leader will maintain good relations to others. The presence encourages diversity in taking risk in prone place. Most important of all is the presence of the nature and form of identification made by a leader who motivates, inspires and excites group or community. 
Belief in the power of magic is common place in Keo community. The existence of magic powers is different from supernatural powers. Magic powers can be contained in heirlooms, armaments, human or other beings. Keo people believe there is a magic man named ata mali, dragon magic, dragon mali or goka beo. The magic powers can serve to immunity, for driving away devils, to resist the enemy, to make changes in the objects into what is desirable, and for certain ceremonies. The habit of using the power of magic to immunity in the area of Keo is using red cloth filled with roots and a flask of oil as a belt.

In this area, it is also used certain objects to banish devils such as sword, keris, spears, sticks, copper knives, and bahar root. In Keo, there is magic saber which it is swung towards the enemy then the enemy will be running scared. Sacred objects are used for certain ceremonies contained in the Mauponggo area. Magic objects, among others are:

(1) podo wea, is the pot of gold to keep round and square shape heirlooms. The pot should not be opened carelessly,

(2) mako wea, a magic shell which is used for periodic ceremonies,

(3) topo pie, a magic machetes which is used to behead enemy's head,

(4) go laba, a gong which is sounded when a chieftain is died, and

(5) doipie, is silver magic coin which is used to pray for the dead.

In the belief of the Keo in the past, creating carvings and sculpture in general is always associated with certain ceremonies. For example, during the ceremony for commemorating important events throughout the human life cycle such as healing the sick, pregnancy, birth, marriage, death and ceremonies around activities related to agriculture. To be able to become a carver or sculptor, a person shall do internship to carver or sculptor as specific requirements that must be fulfilled. Keo community calls this method as toya mali. A person can justifiably be a carver or sculptor without going through the internship process if this person has a direct lineage as a carver or sculptor, for example, a grandfather or a father of the person was a carver or sculptor. Being a carver or sculptor without going through the internship process can lead to disaster, for example, blurred vision and even blindness. This can happen because the spirit of the ruling in the engraving field will be angry with the person who fails to comply with the requirements as determined by the custom and has been in force for generations. Until now there are sculpture artisans (ana deo), which are direct descendant of the earlier sculptors, the grandfather and his father was a sculptor so he became a sculptor without needing to go through the internship process. In the art of sculpture in particular, the Keo culture has only naked woman or man motifs. This symbolizes the life of the ancient people who were sincere and honest. The ana deo existence with a very simple carving, beside to narrate the life of early humans, it also represents things or events that joy and luck where the sculpture is placed in sao waja or sao yeda as village guards so that citizens are protected from a variety of obstacles.

There are also musical instruments as objects which have meaning and function of the relationship with the community. Meaning of an object is manifested in signs or symbols. In this way, the object is functioned as a communication tool. Musical instruments and their music could be a symbol in a variety of ways. This system (music as a tool of communication) is a special culture. Everything is ethno-musicological needs to learn the views of participants who are implementing these cultures in order to understand the meaning of playing the musical instruments. Keo community has a kind of dance called the toda gu. This dance has a uniqueness that describes the cycle of human life from birth until the end of his life. The toda gu dance depicts a journey of life which is full of struggle and fight against human weakness. This dance can be performed only by men who have a family. As for the women can only dance tea eku which means that the women are only able to enjoy the beauty of the world and as a companion of men. So this dance does not describe a struggle, but only a temporary art movement.

Dance and art in the life of Keo community has a high symbol of purity. Both dance and art in the life of Keo community always have motifs associated with belief. These motifs include shrimp and horse motifs. These motifs depict that Keo people believe that the dead is like to be incarnated as river shrimp and changed as terrestrial snakes (nipa mu mara). While the horse motif, in addition to functioning in everyday life, it also serves as a vehicle of the dead. Motifs associated with traditional ceremonies are motifs which are found in the building of traditional house. But, actually it is rather difficult to distinguish motifs associated with belief. This is because the motif associated with beliefs and ceremonies have no clear border. Among the motifs that exist in traditional house like yeda are the roset (octagon animal), dog, vines bun, pig, boat, breasts, man's and woman's genitals, and squat human. All these motifs are closely related to everyday life. Additionally, there are various ceremonies in Keo community relating to birth of a child to life until adulthood. In child birth, Keo community refers it as ghako Keo which means has delivered safely. But, if she gives birth with difficulty, then the community call is as kao ghako that sometimes proverbed as ghako badho which means like died chicks before hatching.

Meanwhile, symbol of prosperity is usually indicated by harvested rice paddy which is placed on the roof of traditional house or on the walls, or put big corn stalks at the traditional house. Sometimes, the harvested rice paddy and 
corn are tied to a pole in peo which is located in the middle of the village. In the life of indigenous Keo community, there are a number of rituals that have been preserved and regarded as a symbol of the culture that have a high value. One of which is still in use is a rite of passage to go through the process of entering adulthood of a family member. In Keo community, the rite is a symbol in undergoing the process of changing a community member when entering adulthood where he is started to be considered as a full member of the tribe, and be actively involved in the community. He has had the same rights and obligations with most members of the tribe, and when the time comes, he will be married or married. Since long time ago when there were still kingdoms, in order to expand the empire, or in order to prevent conflict with other kingdoms, and for the sake of the kingdom itself so that all citizens of the kingdom subdued, the king or his officials had chosen man or woman to be married with the people who came from the village or nobleman. Important people and respectable who are residing in the kingdom will be joined through marriage. Even most people assume that dignity would be lifted if he can marry with the nobleman.

Therefore, since the traditional house has become the center of all social activities, then the Keo community also recognizes kinship system very well. The Keo community, in its offspring principle, is based on descent relationship father lane (patrilineal system). This system works well in implementing the obligations (for example in terms of choosing leadership) as well as in receiving the rights (for example in matters of inheritance, and so on). Male descendant is the desire of a household in the Keo community so that they expect the tasks associated with customs and religious ceremonies will be implemented at the best. Terms in kindship system of the Keo community are composed of several families and have the same terms in the designation of the kinship terms, namely: ebu (designation for grandmother), nusi (designation for grandchildren), ana (designation for children), pame (designation for uncle), pine (designation for aunt), weta (designation for sister), nara (designation for brother), kae (designation for elder brother), and azi (designation for elder sister). In the Keo community whose kindship system is patrilineal, the power is in the hands of the father.

\section{Conclusion}

In this research we revealed the symbolic meanings of Keo traditional houses in the village Lajawajo, in the context social changes. The traditional house is an important building for tribal unity, and called sa'o pu'u if it is meant the building. But if it is intended as a tribal gathering, deliberation, or meeting place, then they call it as sa'o waja. Keo community's traditional house contains of various symbolic meanings that can be used as a medium of reflection in the community in which expressive symbols can help to understand the way of life as well as the process of change, through daily interactions and through cultural idioms used.

\section{References}

Arensberg, Condrad M. \& Arthur H. Niehoff. (1971). Social Change. A Manual for Community Development. Chicago : Aldine-Atherton, Inc.

Ballantine, J. H. (1993). The Sociology of Education: A Systematic Analysis. New Gersy: Prentice Hall.

Bertrand, A. L. (1967). Basic Sociology, an Introduction to Theory and Method, New York: Appletion Century Crofts.

Black, J.A. \& Champion, D.J. (1976). Methods and Issues in Social Research. New York: Wiley.

Broom, Leonard and Selzenick, Phillips (1963) Sociology: A Text with Adopted Readings. New York: Harper and Row.

Geertz, C. (1973). The Interpretartion of Cultures. New York: Basic Books.

Glaser, B., \& Strauss, A. (1967). The discovery of grounded theory: Strategies for qualitative research. London (U.K.): Aldine Transaction.

Keesing, R. M. (1981). Cultural Anthropology: a contemporary perspective, 2nd ed., Holt, Rinehart and Winston.

Kluckhohn, C. (1962). Universal categories of culture: Anthropology Today. Chicago, University of Chicago Press.

Koentjaraningrat. (1990). Pengantar Ilmu Antropologi. Jakarta: Rineka Cipta.

Merriam, S. (2009). Qualitative research: A guide to design and implementation. San Francisco: CA: Jossey-Bass.

Suparlan, P. (1987). Masyarakat: Struktur Sosial dalam Manusia Indonesia Individu Keluarga dan Masyarakat. Jakarta: Akademi Pressindo

Thompson, J. B. (1990). Ideology and Modern Culture. Cambridge: Polity Press 